DOI: $10.15290 /$ pnib.2020.06

ks. Tadeusz Kasabuła

\title{
DEO ET POPULO - Arcybiskup Romuald Jałbrzykowski
}

Dzieje Kościoła katolickiego są częścią dziejów społecznych i politycznych każdego narodu. W poznawanej i znanej nam przeszłości nie wszystko jest do końca jasne i należycie udokumentowane. Brak pełnej prawdy rodzi wokół postaci z przeszłości i wydarzeń z minionych czasów niemało mitów i uproszczeń. Dotyczy to zwłaszcza osób. Ich często dotykają sądy niesprawiedliwe i boleśnie krzywdzące. Ponieważ osąd dotyczy osób, które już nie mogą się bronić, sprawą ambicji historyka powinno być ukazywanie pełnej, na ile pozwalają źródła, prawdy o ludziach przeszłości. A wszystko w tym celu, aby „dać świadectwo prawdzie" i odsłonić rzeczywisty wkład tych osób w dzieje kultury, narodu i Kościoła.

\section{6-1939}

Na skutek przedwczesnej śmierci Metropolity Wileńskiego Jana Cieplaka ${ }^{1}$, papież Pius XI bullą Cum Ecclesia Vestra z 24 czerwca 1926 roku prekonizował dotychczasowego biskupa łomżyńskiego Romualda Jałbrzykowskiego na Arcybiskupa Metropolitę Wileńskiego. Ingres do bazyliki wileńskiej odbył nowy rządca diecezji 8 września t. r. w uroczystość Narodzenia Najświętszej Maryi Panny ${ }^{2}$.

Arcybiskup Romuald Jałbrzykowski, przenosząc się do Wilna, obejmował rządy w Archidiecezji, będącej najbardziej rozległą terytorialnie jednostką administracji kościelnej w ówczesnej Polsce. Na mocy bulli Vixdum Poloniae unitas papieża Piusa XI z 28 października 1925 roku określono ostatecznie granice nowo utworzonej Archidiecezji Wileńskiej. Dokument papieski stanowił potwierdzenie ustaleń Episkopatu Polski z konferencji odbytej w Warszawie 11 sierpnia 1925 roku, zawarte w Propositum deliminationis. W wyniku dokonanych zmian Archidiecezja Wileńska w roku 1926 obejmowała obszar 53860 km², podzielona była na 25 dekanatów, w granicach których znajdowało się 359 parafii, 7 klasztorów i domów zakonnych męskich i 11 domów zakonnych żeńskich.

F. Rutkowski, Arcybiskup Jan Cieplak (1857-1926), Warszawa 1934, s. 349.

2 Bulla nominacyjna, „Wiadomości Metropolitalne Wileńskie” (dalej: WMW), 1 (1926), nr 1, s. III; List pasterski, WMW, 1 (1926), nr 1, s. 148-152. 
Średnia wielkość parafii wynosiła około $150 \mathrm{~km}^{2}$. Zważywszy na ówczesne możliwości komunikacyjne był to obszar ogromny. Liczba katolików sięgała 1202 tys. Opiekę duszpasterską nad nimi sprawowało 467 księży diecezjalnych, 57 duchownych z innych diecezji i kapłani zakonni ${ }^{3}$.

Odbudowa i rozbudowa struktur terytorialnych Archidiecezji podjęta przez abp. Jałbrzykowskiego przyniosła taki owoc, że w latach 1926-1937 liczba placówek duszpasterskich wzrosła do 455, liczba dekanatów z 25 do 30 (powstały nowe dekanaty: Kalwaria, Korycin, Turgiele, Mołodeczno, Worniany, Zdzięcioł). Życie zakonne zaczęło się odnawiać i rozrastać. W latach 1926-1938 przybyło 15 klasztorów i domów zakonnych męskich, 35 klasztorów i domów zakonnych żeńskich oraz 3 klasztory obrządku wschodniego ${ }^{4}$.

Jednym z najpoważniejszych problemów w zarządzie Archidiecezją było ogromne zróżnicowanie jej ludności, pod względem narodowościowym, wyznaniowym, religijnym i obrzędowym. Terytorium zamieszkiwali Polacy, Białorusini, Litwini, Rosjanie, Żydzi, Tatarzy, Karaimi. Zdecydowaną większość stanowili Polacy, ale w wielu dekanatach istniał duży odsetek katolików Litwinów i Białorusinów.

Ludność narodowości litewskiej zamieszkiwała głównie tereny przy granicy z Litwą (Druskienniki, Orany, Olkieniki) i Łotwą (dekanaty Święciany i Brasław), jak również ziemie bliższe Suwalszczyzny. W okolicach Wilna najwięcej Litwinów zamieszkiwało dekanat trocki. Dla potrzeb religijnych ludności litewskiej w Wilnie oddano kościół św. Mikołaja, przy którym parafia liczyła 1643 wiernych. Ludność narodowości białoruskiej i rosyjskiej zamieszkiwała dekanaty wysunięte najbardziej na wschód i północ (Brasław, Miory, Słonim, Święciany, Świr). Używanie przez ludność wiejską języka białoruskiego nie zawsze było jednoznaczne z jej poczuciem przynależności narodowej. Ta świadomość dopiero narastała. W okresie międzywojennym można było mówić raczej o świadomej przynależności terenowej niż narodowej. Ludność ta najczęściej swą przynależność etniczną określała mianem "tutejszy”. Stąd wszelkie spisy ludności, sporządzane dla potrzeb państwa czy Kościoła, mogą się różnić, i to znacznie, w zależności od tego, na co położono akcent przy przeprowadzaniu ankiet. Wyznanie nie pokrywało się ściśle z narodowością (może z wyjątkiem Żydów i Karaimów). Żywioł polski, w przeważającej mierze wyznający katolicyzm, posiadał pewien odsetek wyznawców prawosławia, protestantyzmu czy islamu. Wśród Rosjan, obok prawosławnych, byli także staroobrzędowcy. Do tego trzeba dodać pewną liczbę sekt i odłamów religijnych. Archidiecezja zatem stanowiła niezwykle urozmaiconą mozaikę narodowościową, religijną, wyznaniową i obrzędową ${ }^{5}$.

B. Kumor, Granice metropolii i diecezji polskich (968-1939), „Archiwa, Biblioteki i Muzea Kościelne”, 22 (1971), s. 319-322.

$4 \quad$ Catalogus ecclesiarum et cleri archidoecesis vilnensis pro Anno Domini 1927-1939, Vilnae 1927-1939.

5 Archiwum Archidiecezjalne w Białymstoku - bez sygn. (dalej: AAB), Dane statystyczne Archidiecezji Wileńskiej. Statystyka narodowościowa i wyznaniowa za lata 1933 i 1938. 
Tak złożona i skomplikowana struktura narodowościowa i wyznaniowa Archidiecezji w okresie międzywojennym w nieokrzepłych jeszcze strukturach wskrzeszonego państwa polskiego generowała konflikty także na gruncie kościelnym. Arcybiskup Jałbrzykowski, obejmując Archidiecezję Wileńską, stanął wobec wielu nabrzmiałych problemów, wymagających od nowego rządcy ogromnej odwagi, elastyczności w podejmowaniu decyzji i zmysłu dyplomaty, zwłaszcza w kwestiach narodowościowo-wyznaniowych, a więc siłą rzeczy ocierających się, wręcz wchodzących na teren polityki państwa wobec mniejszości narodowych. Z jednej strony musiał być w jednakowym stopniu pasterzem wszystkich, oddanych jego duszpasterskiej pieczy wiernych, również mniejszości litewskiej, jak też coraz bardziej świadomych swej przynależności narodowościowej katolików-Białorusinów, a z drugiej - zmuszony był respektować pryncypia polityki wyznaniowej władz państwowych, które, obiektywnie przyznać należy, dążąc do unifikacji państwa, pozostawiały bardzo wąski margines tendencjom emancypacyjnym mniejszości na Kresach Wschodnich, panicznie bojąc się, co w szerszym kontekście nie dziwi, ich skłonności separatystycznych. Obawy te miały istotnie, w wielu przypadkach, uzasadnienie w rzeczywistości ${ }^{6}$.

Bezpośrednio po objęciu stolicy biskupiej przez abp. Jałbrzykowskiego konflikty na tym tle nieco przygasły. Znając aspiracje narodowościowe mniejszości litewskiej, Jałbrzykowski, podobnie jak to uczynił wcześniej w Seminarium Duchownym w Sejnach, również w Wilnie nakazał naukę języka litewskiego wszystkim klerykom bez wyjątku. Przygotowani w ten sposób duszpasterze, bez względu na ich narodowość, mieli zaspokajać potrzeby religijne ludności litewskiej, zwłaszcza w dekanatach z większą jej liczbą. Problem w tym, że według oceny absolwentów Seminarium, uczący tego języka ks. Wincenty Taszkun, nie wymagał zbyt wiele. Niektórzy odnosili wrażenie, że „uczył tak, by nie nauczyć". Tak więc, dla księży-Polaków kończących wileńskie Seminarium, generalnie litewski pozostawał nadal językiem obcym. To z kolei rodziło podejrzenia, że abp Jałbrzykowski prowadzi politykę narodową mającą na celu asymilację ludności litewskiej ${ }^{7}$.

Duchowni opowiadający się zdecydowanie za narodowością litewską czy białoruską zwykli, co zresztą w ówczesnych warunkach nie powinno dziwić, korzystać z ambon i gmachów świątyń dla prowadzenia działalności pozareligijnej - narodowościowej i społecznej. Oni wszak stanowili elitę intelektualną swego narodu. Inna sprawa, że ta aktywność niekiedy przeradzała się w agitację antypolską, co czynnikom polskim - państwowym i kościelnym, rzecz jasna, podobać się nie mogło. Władze polskie, tak uczulone na punkcie jedności i suwerenności odrodzonego właśnie państwa, patrzyły na te harce co najmniej

M. Moroz, „Krynica”. Ideologia i przywódcy białoruskiego katolicyzmu, Białystok 2001, s. 154-164; T. Kasabuła, "Chryścijanskaja Dumka” (1928-1939), "Studia Teologiczne. Białystok Drohiczyn Łomża”, 21 (2003), s. 269-288.

7 A. Szot, Abp Romuald Jałbrzykowski metropolita wileński, Lublin 2002, s. 56-58. 
niechętnie i hamowały zapędy co bardziej aktywnych działaczy litewskich, w tym także duchownych ${ }^{8}$.

W 1927 roku uznano, że miara się przebrała. W październiku tego roku na terenie województwa wileńskiego za jednym zamachem zamknięto 48 szkół powszechnych litewskich i aresztowano kilkadziesiąt osób, stawiając im zarzut agitacji antypolskiej i kolportowania nielegalnych ulotek. Uwięziono pięciu księży z Wilna zarzucając im głoszenie kazań o charakterze antypaństwowym. W tej grupie znalazł się proboszcz parafii św. Mikołaja w Wilnie i redaktor tygodnika „Kelias” ks. Piotr Kraujalis oraz księża: Krzysztof Czybiras, Franciszek Bielawski, Nikodem Rasztutis i Wincenty Taszkun. W powiecie święciańskim aresztowano księży: Aleksandra Michajłę, Wincentego Bobina i Wincentego Krysztopanisa. Ordynariusz wileński nie dezawuował decyzji władz, jednakże wystosował do wojewody wileńskiego list z prośbą o zwolnienie księży, zgłaszając jednocześnie gotowość złożenia ewentualnych poręczeń. Wstawiennictwo to przyniosło częściowy skutek. Już w trzy dni później zwolniono z aresztu księży Kraujalisa i Taszkuna9.

Niezmiernie trudno, jeżeli w ogóle możliwe jest, dać pełną i jednoznaczną ocenę konkretnej osoby i jej działalności, tym bardziej jeżeli mamy do czynienia z postacią, której wypadało żyć i działać w warunkach niezwykle skomplikowanych, w których każda niemal decyzja mogła budzić kontrowersje. Arcybiskup Jałbrzykowski był człowiekiem wielkiej wiary i głębokiej, autentycznej pobożności. Był tytanem pracy. Od siebie wymagał wiele, wysokie wymagania stawiał też innym. Nic dziwnego, że prezbiterat diecezji nie zawsze nadążał za swoim pasterzem, co z kolei owocowało częstymi translokatami duchownych i odwoływaniem się do kar kościelnych. W kościelnej historiografii polskiej funkcjonuje obraz Arcybiskupa kreślony zdecydowanie jasnymi barwami. Rzut oka na przedwojenną jego działalność z pewnej już perspektywy, każe jednak pewne sądy nieco skorygować, bo rzeczywiście, ostrożnie jedynie sygnalizowane w treści dotychczasowych opracowań, niektóre postawy Arcybiskupa rzucają wąską smugę cienia na ów świetlany jego portret. Trudno zapisać na plus rządcy diecezji fakt, że wizytacje pasterskie odbywał w niebywałym pośpiechu, nierzadko po trzy parafie dziennie, siłą rzeczy widząc i oceniając często jedynie fasadę sprefabrykowaną na okoliczność jego przyjazdu. Temperament miał gwałtowny, w ogóle był porywczy, chociaż generalnie nad emocjami panował, co było efektem wytężonej pracy nad sobą. Wszystko to świadczy o niezwykle ciekawej, złożonej i bogatej osobowości. To nie był chodzący posąg. Takiego człowieka potrzebował ówczesny lokalny, odradzający się Kościół wileński, zdecydowanego i konsekwentnego w działaniu. Takiego potrzebował i takiego otrzymał.

T. Kasabuła, Rec. M. Moroz, „Krynica”. Ideologia i przywódcy białoruskiego katolicyzmu, Białystok 2001, ss. 230, [w:] „Studia Teologiczne. Białystok Drohiczyn Łomża”, 20 (2002), s. 520-524.

9 „Słowo”, 6 (1927), nr 50, s. 3, nr 55, s. 3, nr 228, s. 1, nr 232, s. 1. 


\section{9-1945}

Tuż przed wybuchem wojny abp Jałbrzykowski przeszedł ciężką chorobę, tak poważną, że zaczęto obawiać się o jego życie. W sierpniu 1939 roku jednak stan zdrowia rządcy diecezji poprawił się na tyle, że na skutek rozwoju sytuacji politycznej w Europie generującej możliwość wybuchu wojny, Metropolita zadbał, by przygotować podległe mu duchowieństwo do działania w warunkach międzynarodowego konfliktu zbrojnego. Myślał o rozwiązaniach gwarantujących ciągłość administrowania diecezją w warunkach ewentualnej wojny ${ }^{10}$. Gdy wybuchła, Arcybiskup już w pierwszej połowie września 1939 roku udzielił kilku dziekanom specjalnych uprawnieńn ${ }^{11}$, które rozszerzył 2 października, by wreszcie 9 października udzielić uprawnień wikariuszy generalnych wszystkim dziekanom, które to uprawnienia zostały poszerzone i bardziej skonkretyzowane kolejnymi pismami z 15 i 23 października ${ }^{12}$.

Tymczasem Wilno już 18 września 1939 roku zostało zajęte przez wojska sowieckie $^{13}$. W wyniku porozumienia między Związkiem Sowieckim a Litwą z 10 października t. r. część Wileńszczyzny z Wilnem została przekazana Litwie, na skutek czego 28 października wojska litewskie wkroczyły do Wilna. Wkrótce władze litewskie poczęły czynić u Stolicy Apostolskiej zabiegi o odsunięcie abp. Jałbrzykowskiego od zarządu diecezją. Wobec nieskuteczności tych starań władze litewskie dały miejscowym nacjonalistom zielone światło na organizowanie demonstracji w kościołach wileńskich i przed pałacem arcybiskupim. W kwietniu i maju 1940 roku wystąpienia antypolskie, których strategicznym celem było nie tylko wprowadzenie nabożeństw litewskich do kościołów wileńskich, ale przede wszystkim wywarcie nacisku na Arcybiskupa, by de facto zrezygnował z rządów diecezją, osiągnęły apogeum ${ }^{14}$. Kres działaniom litewskich środowisk nacjonalistycznych położyła aneksja Litwy przez Związek Sowiecki w czerwcu 1940 roku, przez co sytuacja Arcybiskupa wprawdzie zmieniła się, ale przez to stała się jeszcze bardziej złożona, zarówno w sferze politycznej, jak i kościelnej. Sowieckie władze z miejsca zaczęły wprowadzać w życie mechanizm swych rządów, który jeszcze dotkliwiej ograniczał działalność Kościoła. Już latem 1940 roku przejęto archiwa kościelne, w tym cały dział ksiąg metrycznych. Skonfiskowany zasób przekazano urzędom stanu cywilnego w Baranowiczach, Białymstoku, Wilejce i w Wilnie. Schyłek roku 1940 roku zaowocował eksmisją Arcybiskupa z jego rezydencji i konfiskatą budynku kurialnego przy

10 Archiwum Archidiecezjalne w Białymstoku, bez sygn. (dalej AAB), S. Czyżewski, Ks. Dr Romuald Jałbrzykowski arcybiskup metropolita wileński. Wspomnienia, (mps), s. 224-225.

11 AAB, Materiały po ks. Aleksandrze Chodyce, b.n.s.

12 T. Krahel, Zarządzanie archidiecezją wileńska w czasie II wojny światowej, „Studia Teologiczne. Białystok Drohiczyn Łomża", 4 (1986), s. 125-127.

13 L. Tomaszewski, Wileńszczyzna lat wojny i okupacji 1939-1945, Warszawa 1999, s. 43-44; H. Wisner, Litwa. Dzieje państwa i narodu, Warszawa 1999, s. 212.

14 P. Łossowski, Litwa a sprawy polskie 1939-1940, Warszawa 1982, s. 277-297; T. Krahel, Archidiecezja wileńska, [w:] Życie religijne w Polsce pod okupacja 1939-1945, red. Z. Zieliński, Katowice 1992, s. 19. 
ul. Marii Magdaleny. Przeznaczono go na siedzibę Centralnego Komitetu Komunistycznej Partii Litwy. Arcybiskupowi Jałbrzykowskiemu pozwolono na osiedlenie się w starym lokalu przy ul. Zamkowej 8 . Tam też przeniesiono Kurię Metropolitalną ${ }^{15}$.

Wybuch wojny niemiecko-sowieckiej przyniósł zmianę okupanta i zmianę założeń polityki eksterminacyjnej na zajętych przez wojska hitlerowskie ziemiach. Taki bieg wydarzeń zmusił rządcę Archidiecezji Wileńskiej do podjęcia nowych wyzwań. Niezwykle pilną sprawą stało się zapewnienie wiernym na okupowanej Białorusi opieki duszpasterskiej. Stąd też już w październiku 1941 roku abp Jałbrzykowski otrzymał na mocy dokumentu, wystawionego 20 września 1941 roku z upoważnienia kardynała Maglione przez nuncjusza z Berlina Orsenigo, władzę administratora apostolskiego i nadzwyczajne uprawnienia na tereny diecezji mińskiej i Archidiecezji Mohylewskiej. Arcybiskup zaczął posyłać kapłanów swej diecezji na powierzone jego duszpasterskiej pieczy tereny. Działalność ta wobec wrogiego stosunku władz niemieckich i nacjonalistów białoruskich do polskich kapłanów została wkrótce w dramatycznych okolicznościach przerwana. Już 9 listopada 1941 roku został zamordowany przez Niemców koło Borysowa ks. Henryk Hlebowicz, później jeszcze inni kapłani. Coraz silniejszy od jesieni tego roku terror hitlerowski na tych ziemiach sprawiał, że każdy przejaw działalności duszpasterskiej spotykał się z surowymi represjami ${ }^{16}$.

Arcybiskup Jałbrzykowski już u początku działalności polskiego zbrojnego podziemia na Wileńszczyźnie roztoczył opieką duszpasterską jego żołnierzy. Temu celowi miało służyć skierowanie o. Kazimierza Kucharskiego, jezuitę, oraz ks. Romualda Świrkowskiego do kontaktów z formującymi się strukturami polskiego zbrojnego podziemia. Nie byli oni zapewne jedynymi duchownymi działającymi przy tajnych oddziałach. Ich postacie jawią się w świetle źródeł stąd, że o. Kucharski wiosną 1942 roku został uwięziony przez sowietów, zaś ks. Świrkowski rozstrzelany przez Niemców w Ponarach w maju 1942 roku. Na koordynatora duszpasterstwa wojskowego w oddziałach podziemnej walki zbrojnej abp Jałbrzykowski wyznaczył ks. Piotra Rynkiewicza ${ }^{17}$.

Dnia 3 marca 1942 roku niemieckie represje brutalnie dotknęły Seminarium Duchowne w Wilnie i duchowieństwo parafii wileńskich. Niemal wszyscy profesorowie i wielu księży parafialnych zostało tego dnia aresztowanych, wkrótce taki sam los spotkał zakonników i siostry zakonne. Wreszcie 22 marca 1942 roku aresztowano i wywieziono z Wilna do Wiłkowyszek abp. Jałbrzykowskiego i kanclerza Kurii, ks. Adama Sawickiego. Arcybiskup został internowany w klasztorze Księży Marianów w Mariampolu. Rządy w Archidiecezji objął

15 S. Czyżewski, Ks. Dr Romuald Jałbrzykowski arcybiskup metropolita wileński. Wspomnienia, (mps w AAB), s. 237.

16 T. Krahel, Zarzadzanie, s. 128-129; Idem, Błogosławiony Henryk Hlebowicz, Białystok 1999, s. 56-64.

17 Idem, Archidiecezja wileńska, s. 59-60. 
abp Reinys jako administrator apostolski. Arcybiskup Jałbrzykowski, chociaż uwięziony, miał możliwości, co prawda, bardzo ograniczone, kontaktu z diecezją. Odwiedzała go kilka razy szarytka, s. Maria Nowak, ks. Stanisław Czyżewski, alumn Kazimierz Wilczewski, a Jadwiga Michniewiczówna przywoziła potrzebne lekarstwa. Nadto ks. Sawickiemu udało się kilkakrotnie załatwić Arcypasterzowi przepustki na wizyty u lekarza w Wilnie. Arcybiskup pozostawał internowany aż do zajęcia Mariampola przez wojska sowieckie 1 sierpnia 1944 roku ${ }^{18}$.

Metropolita dotarł do Wilna 5 sierpnia 1944 roku i już następnego dnia, w uroczystość Przemienienia Pańskiego w katedrze przemówił do licznie zgromadzonych wiernych. Rozpoczął się nowy okres pracy. Wracali z obozów profesorowie, przybywali klerycy. Jesienią Arcybiskup wznowił działalność Seminarium Duchownego i zaczął porządkować sprawy administracyjne w zniszczonej działaniami wojennymi i kolejnymi okupacjami diecezji. Obsadzał parafie na Wileńszczyźnie, znowu zaczął wysyłać księży na tereny diecezji mińskiej i Archidiecezji Mohylewskiej. Nie oznaczało to jednak wskrzeszenia duszpasterstwa i życia religijnego wiernych w normalnych ramach. Władze sowieckie nie pozwalały na wiele i zaledwie kilku kapłanom przez jakiś czas udało się tam pozostać. Ponadto na Wileńszczyźnie trwały aresztowania oraz repatriacja ludności do Polski. W obawie przed więzieniem, bądź wywózką na Sybir wyjeżdżali też duchowni, chociaż Arcybiskup wyraźnie zabraniał księżom opuszczać placówki duszpasterskie. Chciał, aby parafie nie pozostawały bez duszpasterzy. On sam permanentnie był inwigilowany przez sowieckie służby bezpieczeństwa. Na początku 1945 roku litewskie organy NKWD rozpoczęły akcję, której celem było „ujęcie najbardziej aktywnych uczestników polskiego nacjonalistycznego podziemia i jego inspiratorów ze środowiska duchowieństwa katolickiego" $^{\prime 19}$. Wczesnym rankiem 25 stycznia 1945 roku do rezydencji arcybiskupiej weszli funkcjonariusze NKWD. Rozpoczęła się szczegółowa, bezpardonowa rewizja. Przeszukano dokładnie gmach Kurii Metropolitalnej Wileńskiej i pałac arcybiskupi nie oszczędzając kaplicy, w której zerwano nawet podłogę ${ }^{20}$. Rewizja trwała do godz. 2.00. Po jej zakończeniu aresztowano Arcybiskupa i ks. Adama Sawickiego. Umieszczono ich w więzieniu przy ul. Ofiarnej na Łukiszkach. Decyzja o aresztowaniu - według akt sądowych - została podpisana 19 stycznia 1945 roku $^{21}$. Arcybiskup Jałbrzykowski był przetrzymywany w bardzo złych warunkach. Mała cela w podziemiach więzienia, brudna, zawszona, była nie tylko nieogrzewana, ale brakowało w niej nawet szyb. Przez pierwsze dni nie miał wody do mycia. Warunki, w jakich przebywał stwarzały zagrożenie dla jego

\footnotetext{
$18 \quad$ S. Czyżewski, op. cit., s. 244 nn.

19 T. Krahel, Arcybiskup Romuald Jałbrzykowski w sowieckim więzieniu, „W Służbie Miłosierdzia”, 6 (2005), nr 9, s. 14 .

20 S. Czyżewski, op. cit., s. 275.

21 T. Krahel, Arcybiskup Romuald Jałbrzykowski w sowieckim więzieniu, s. 14.
} 
życia. „W więzieniu nie miał ani chwili spokoju, bo w dzień wciąż zaglądali do okienek, albo wpadała z hałasem «komisja», pytając, czy nie ma jakiegoś żądania [...]. W nocy natomiast o godz. 23.00 na kilka godzin zabierali go na badania, po których Arcypasterz wracał bardzo zmęczony, z wypiekami na policzkach" wspominała s. Maria Nowak, szarytka, która zgodziła się dobrowolnie pójść do więzienia, by pielęgnować tam ciężko chorego na nerki i zapalenie stawów Arcybiskupa ${ }^{22}$. Pozwolenie na odprawianie Mszy św. otrzymał dopiero na dzień przed uwolnieniem ${ }^{23}$. Arcybiskup przebywał w celi więziennej prawie miesiąc, po czym 20 lutego 1945 roku zapadła decyzja o jego zwolnieniu ze względu na zły stan zdrowia i potrzebę specjalistycznego leczenia. Zobowiązano go do nieopuszczania granic miasta, po czym w nocy 24 lutego odwieziono do domu ${ }^{24}$.

Zwolnienie z więzienia nie oznaczało końca śledztwa. Do połowy maja był kilkakrotnie wzywany na przesłuchania. Sprawę abp. Jałbrzykowskiego zakończono 25 maja 1945 roku sformułowaniem aktu oskarżenia zarzucając mu, że w latach 1940-1941 był jednym z inspiratorów podziemnej polskiej antysowieckiej organizacji Związek Walki Zbrojnej, zarzucono mu współpracę z Delegaturą Rządu Polskiego na Kraj, z Armią Krajową, a po powtórnym wkroczeniu armii sowieckiej w 1944 roku - o popieranie antysowieckiego polskiego podziemia. Ostatecznie Kolegium Specjalne w Moskwie 4 czerwca 1945 roku wydało decyzję: „wydworit’ iz rajonow Sowietskogo Sojuza”, co oznaczało wyrok nakazujący opuszczenie granic Związku Sowieckiego i wyjazd do Polski²5. Arcybiskup Jałbrzykowski o nakazie wyjazdu dowiedział się dopiero na początku lipca 1945 roku, po tym, jak „odwiedzili” go funkcjonariusze NKWD z nakazem opuszczenia Wilna w ciągu trzech dni. Ostatecznie Arcybiskup otrzymał 10 dni na spakowanie się i wyjazd. Metropolita wileński opuścił stolicę diecezji 14 lipca i następnego dnia (15 lipca 1945) przybył do Białegostoku, gdzie zamieszkał na plebanii parafii farnej ${ }^{26}$.

Represje sowieckie dotknęły też Seminarium Duchowne w Wilnie. Dnia 20 lutego 1945 roku alumnom narodowości polskiej nakazano wyjazd do Polski, natomiast klerykom - Litwinom przeniesienie się do Seminarium w Kownie. Decyzję tę obwieścił oficer sowiecki przerywając bezceremonialnie wykład ks. prof. Pawła Nowickiego. Nie wdając się w szczegóły stwierdził krótko: „Nu, tiepier' Litowcy ujezżajtie w Kaunas w seminar, a Poliaki priamo ubierajties' k czortu w Polszu"27. Tak więc 24 lutego Arcybiskup podjął decyzję o przeniesieniu

\footnotetext{
22 AAB, Relacja s. Marii Nowak z pobytu abp. R. Jałbrzykowskiego w więzieniu, (mps).

23 Ks. A. Sawicki pozostał w więzieniu. Wywieziono go do obozu pracy w głąb Rosji. Powrócił do Wilna w 1947 r.; L. Tomaszewski, Kronika wileńska 1941-1945, Warszawa 1992, s. 138-139.

24 T. Krahel, Martyrologia duchowieństwa archidiecezji wileńskiej 1939-1945, Białystok 2017, s. 179-185.

25 I. Mikłaszewicz, Polityka sowiecka wobec Kościoła katolickiego na Litwie 1944-1965, Warszawa 2001, s. 175176; A. Szot, Abp Romuald Jałbrzykowski metropolita wileński, Lublin 2002, s. 281.

26 S. Czyżewski, op. cit., s. 282-284; T. Krahel, Między wyzwoleniem a końcem wojny, [w:] Archidiecezja wileńska w latach II wojny światowej. Studia i szkice, red. T. Krahel, Białystok 2014, s. 246.

27 Cyt. za T. Krahel, Dzieje Archidiecezjalnego Wyższego Seminarium Duchownego w Białymstoku, [w:] Archidiecezjalne Wyższe Seminarium Duchowne w Białymstoku 1945-1995. Księga Jubileuszowa, red. S. Hołodok,
} 
Seminarium do Białegostoku. Tutaj wiosną 1945 roku przybyli profesorowie Wydziału Teologicznego Uniwersytetu Stefana Batorego (USB) i Seminarium Duchownego oraz alumni. Wygnańców na miejscu powitał i otoczył opieką dziekan białostocki, ks. Aleksander Chodyko, który postarał się o siedzibę dla wypędzonej uczelni. Kiedy wojska sowieckie opuściły dom braci zakonnych przy ul. Słonimskiej 8, wileńskie Seminarium 8 maja 1945 roku mogło tam zainaugurować pracę ${ }^{28}$. W ten oto sposób Wydział Teologiczny USB z Seminarium Duchownym stał się pierwszą wyższą uczelnią w dziejach Białegostoku. Tak więc nie było najgorzej, ale i to wkrótce się skończyło, bo w trzy lata później (1948 r.) władze zlikwidowały Wydział Teologiczny, czarne chmury i widmo likwidacji zawisły nawet nad Seminarium Duchownym.

\section{5-1955}

Tymczasem w Białymstoku w krótkim czasie uformowała się Kuria Arcybiskupia, a we wrześniu 1945 roku działał już sąd arcybiskupi, tu też znalazła się część prałatów i kanoników Kapituły Bazyliki Metropolitalnej Wileńskiej. W Białymstoku zatem zaistniał ośrodek administracji kościelnej Archidiecezji Wileńskiej, którego powstanie nierozerwalnie związane jest z osobą abp. Jałbrzykowskiego. Ten zaś pasterzował na małym skrawku Archidiecezji, mimo że podlegało mu całe arcybiskupstwo, chociaż bez możliwości bezpośredniego kontaktu z zakordonową jego częścią. Sytuację rozwiązano w ten sposób, że w Wilnie litewską częścią Archidiecezji zarządzał jako wikariusz generalny abp Mieczysław Reinys, natomiast w największej części, tej w granicach Białoruskiej Republiki Sowieckiej, tymczasową władzę sprawowali trzej wikariusze generalni, dziekani: w Grodnie - ks. Antoni Kuryłowicz, w Lidzie - ks. Hipolit Bojaruniec i w Głębokiem - ks. Antoni Zienkiewicz. Wszyscy działali na mocy nominacji abp. Jałbrzykowskiego. Jemu też podlegali kapłani wileńscy, którzy wyjechali z terytorium Związku Sowieckiego i pracowali na tzw. Ziemiach Odzyskanych lub w innych diecezjach ${ }^{29}$.

Białostocka część Archidiecezji Wileńskiej w 1946 roku obejmowała obszar 6263 km², liczyła ponad 235 tysięcy wiernych w 56 parafiach, które należały do następujących dekanatów: białostockiego, dąbrowskiego, knyszyńskiego, korycińskiego, sokólskiego oraz brzostowickiego (Krynki). Dwie parafie z dekanatu wołkowyskiego: Białowieża i Narewka zostały włączone do dekanatu białostockiego ${ }^{30}$.

Białystok 1995, s. 12, przyp. 14.

28 Tbidem, s. 12-14.

29 T. Kasabuła, Dzieje Archidiecezji Białostockiej, [w:] Schematyzm Archidiecezji Białostockiej 2014, red. J. Jabłoński i in., Białystok 2014, s. 60.

30 Idem, Rozwój sieci kościołów parafialnych, rektoralnych i pomocniczych w archidiecezji w Białymstoku w latach 1945-1989, „Rocznik Teologii Katolickiej”, 6 (2007), s. 159-160. 
Metropolita Wileński, mimo że wygnanie z Wilna uważał za sytuację tymczasową, z miejsca przystąpił do działania: tworzył nowe parafie (tylko w latach 1945-1946 powstało ich sześć), zwizytował wszystkie parafie, wszędzie udzielając sakramentu bierzmowania. Żeby podnieść religijność i moralność wiernych w pierwszych latach powojennych zarządził we wszystkich parafiach misje parafialne. Te były wyjątkowo potrzebne, jako że wojna i kolejne okupacje dokonały wśród wiernych moralnego spustoszenia. Plagą prawdziwą było pijaństwo ze wszystkimi jego skutkami. Trudno się temu dziwić, skoro właśnie „,bimber” w czasach okupacji był nieraz jedynym dostępnym i w ogóle akceptowanym środkiem płatniczym i to bez względu na okupanta. Niejeden ksiądz tym sposobem uratował kościół parafialny przed zupełnym zniszczeniem przez cofających się Niemców ${ }^{31}$.

Rozwijający się białostocki ośrodek administracji kościelnej był dla umacniającej się władzy "ludowej” nie do zaakceptowania, zatem we wrześniu roku 1950, nakazano abp. Jałbrzykowskiemu, aby ten "zlikwidował Seminarium, rozwiązał Kurię w Białymstoku, a sam wyjechał na Zachód". Już tylko ustnie poinformowano, że wyznaczono mu miejsce pobytu we Wrocławiu, a termin wyjazdu określono na 26 września. Zapobiegliwe Siostry Szarytki zaproponowały Metropolicie na zamieszkanie jeden ze swoich domów pod Warszawą, w Ignacowie lub Otwocku. Arcybiskup natomiast zamierzał osiąść bliżej, bo na plebanii w Ostrowi Mazowieckiej. Siostry zakonne rozpoczęły już pakowanie rzeczy arcybiskupich, a ks. Adam Sawicki - starania u władz państwowych o anulowanie podjętej decyzji. Jego zabiegi i determinacja w dużym stopniu przyczyniły się do tego, że jednak Metropolita Wileński pozostał w Białymstoku. Tym samym udało się uchronić przed likwidacją białostocki ośrodek administracji kościelnej. Ostatecznie 29 września władze państwowe powiadomiły, że „,ks. Metropolita pozostaje na miejscu pod warunkiem, że Kuria odtąd w Białymstoku nie będzie się nazywała «wileńską», a księża pracujący w diecezjach na Ziemiach Odzyskanych podlegać będą miejscowym władzom kościelnym". Tak więc odtąd na określenie białostockiego ośrodka administracji kościelnej, Archidiecezji Wileńskiej z siedzibą w Białymstoku przyjęła się nazwa "Archidiecezja w Białymstoku" ${ }^{\prime 2}$.

W tym kontekście wspomnieć należy, że zanim podjęto próbę usunięcia Arcybiskupa z Białegostoku, komuniści zdążyli już zlikwidować Wydział Teologiczny USB. Miało to miejsce w 1948 roku. Zresztą znaczną część profesorów Wydziału powołano na stolice biskupie: w Siedlcach osiadł bp Ignacy Świrski, w Łodzi - bp Michał Klepacz, w Łomży - bp Czesław Falkowski, we Włocławku

Idem, Dzieje Archidiecezji Białostockiej, s. 60.

32 A. Szot, Arcybiskup Romuald Jałbrzykowski na białostockiej ziemi (1945-1955), [w:] Między Wilnem a BiaŁymstokiem, red. T. Kasabuła, J.J. Milewski, Białystok 2005, s. 104-107. 
- bp Antoni Pawłowski. Biskupami pomocniczymi zostali księża profesorowie: Władysław Suszyński w Białymstoku i Aleksander Mościcki w Łomży ${ }^{33}$.

Tymczasem proces odbudowy sieci parafialnej i organizacji duszpasterstwa w nowych warunkach postępował dość sprawnie. Już w lipcu 1945 roku wszystkie placówki duszpasterskie były obsadzone, w miarę szybko zlikwidowano zniszczenia wojenne, rozpoczęto budowę nowych świątyń. Stała tendencja i świadome dążenie do usprawnienia organizacyjnego, mającego na celu stworzenie lepszych warunków dla duszpasterstwa, pomimo represyjnej polityki władz, ograniczeń i barier administracyjnych, była zasługą abp. Jałbrzykowskiego. Ale nie tylko. Rozbudowa sieci parafialnej nie byłaby możliwa bez ogromnego, nieporównywalnego z poprzednim okresem, zaangażowania społeczności parafialnych oraz przyjmowania przez wiernych obciążeń finansowych na rzecz tworzenia nowych parafii i budowy kościołów. Zjawisko to, obok zmienionych warunków polityczno-gospodarczych, miało swe źródło w duszpasterskim oddziaływaniu na wiernych. Na ten aspekt działalności duszpasterskiej położono w tym okresie szczególny nacisk. Owoce tych wysiłków są trwałe do dziś, o czym świadczy fakt, że utworzona w 1991 roku w miejsce administratury apostolskiej pod nazwą Archidiecezja w Białymstoku, diecezja, a w 1992 roku Archidiecezja Białostocka, zamieszkała przez około 400 tys. katolików, w 1992 roku obejmowała już osiem dekanatów i 81 parafii, czyli o 30 ośrodków parafialnych więcej niż w roku $1945^{34}$.

Ostatnie lata życia abp. Jałbrzykowskiego naznaczone były chorobą i cierpieniem. Były to skutki wcześniejszych operacji i przeżyć okresu wojny i kolejnych okupacji. Od 22 marca 1954 do 11 czerwca 1955 roku odprawiał Msze św. już tylko w prywatnej kaplicy ${ }^{35}$.

Arcybiskup Romuald Jałbrzykowski zmarł 19 czerwca 1955 roku o godz. 12.55. Jego doczesne szczątki złożono w kaplicy na plebanii farnej, a następnego dnia przeniesiono do starego kościoła farnego, gdzie w otwartej trumnie spoczywały do środy 22 czerwca 1955 roku. W dniu pogrzebu, 22 czerwca 1955 roku, o godz. 16.30 przeniesiono ciało zmarłego ze starego kościoła do prokatedry. Trumnę nieśli kapłani, których sam wyświęcił. Mszę św. odprawił ordynariusz siedlecki, bp Ignacy Świrski, pierwszy z konsekrowanych w Białymstoku biskupów. On też przewodniczył konduktowi żałobnemu ${ }^{36}$. Zwłoki abp. Jałbrzykowskiego zostały złożone w bocznej kaplicy w prokatedrze białostockiej. Grobowiec wykuto w ścianie w miejscu, gdzie stał konfesjonał, w którym codziennie

T. Krahel, Dzieje Archidiecezjalnego Wyższego Seminarium Duchownego w Białymstoku, s. 18-20.

T. Kasabuła, Dzieje Archidiecezji Białostockiej, s. 61.

AAB, Wspomnienia s. Heleny Mańkowskiej o abp. R. Jałbrzykowskim, [mps], s. 7-10.

36 M. Paszkiewicz, Ś. P. Arcybiskup Romuald Jałbrzykowski wzorem kapłana, "Wiadomości Kościelne”, 1 (1957), nr 4-5, s. 142; Idem, Dziesięciolecie rządów arcybiskupa Romualda Jałbrzykowskiego w Białymstoku (1945-1955), „Wiadomości Kościelne Archidiecezji w Białymstoku”, 6 (1980), nr 2, s. 96; W. Pietkun, Kazanie wygłoszone wieczorem w dniu zgonu Arcybiskupa w kościele św. Rocha, „Wiadomości Kościelne”, 1 (1957), nr 4-5, s. 146-149. 
spowiadał. Udział w uroczystościach pogrzebowych wzięło 15 biskupów, 4 infułatów, przedstawiciele kapituł katedralnych i ponad 300 kapłanów ${ }^{37}$.

Pogrzeb był „prosty i surowy, taki jak jego życie. Trumna ze zwykłych, tylko heblowanych desek, stojąca na sosnowych krzyżakach, cztery świece, krzyż i pastorał u wezgłowia. Nie pozwolił na żadne kwiaty. Więc jedynym hołdem mu złożonym były łzy ogromnej rzeszy obecnych"38.

\section{Bibliografia}

AAB, A. Jałbrzykowska, Nasz stryj, Kraków 1972 [mps].

$\mathrm{AAB}$, Materiały po ks. Aleksandrze Chodyce, b.n.s.

AAB, Relacja s. Marii Nowak z pobytu abp. R. Jałbrzykowskiego w więzieniu, (mps).

AAB, Wspomnienia s. Heleny Mańkowskiej o abp. R. Jałbrzykowskim, [mps].

Archiwum Archidiecezjalne w Białymstoku - bez sygn. (dalej: AAB), Dane statystyczne Archidiecezji Wileńskiej. Statystyka narodowościowa i wyznaniowa za lata 1933 i 1938.

Bulla nominacyjna, „Wiadomości Metropolitalne Wileńskie” (dalej: WMW), 1 (1926), $\mathrm{nr} 1$

Catalogus ecclesiarum et cleri archidoecesis vilnensis pro Anno Domini 1927-1939, Vilnae 1927-1939.

Czyżewski S., Ks. Dr Romuald Jałbrzykowski arcybiskup metropolita wileński. Wspomnienia, (mps w AAB).

Kasabuła T., Dzieje Archidiecezji Białostockiej, [w:] Schematyzm Archidiecezji Białostockiej 2014, red. J. Jabłoński i in., Białystok 2014.

Kasabuła T., Rec. M. Moroz, „Krynica”. Ideologia i przywódcy białoruskiego katolicyzmu, Białystok 2001, ss. 230, [w:] „Studia Teologiczne. Białystok Drohiczyn Łomża", 20 (2002).

Kasabuła T., Rozwój sieci kościołów parafialnych, rektoralnych i pomocniczych w archidiecezji w Białymstoku w latach 1945-1989, „,Rocznik Teologii Katolickiej”, 6 (2007).

Kasabuła T., "Chryścijanskaja Dumka” (1928-1939), „Studia Teologiczne. Białystok Drohiczyn Łomża", 21 (2003).

Krahel T., Archidiecezja wileńska, [w:] Życie religijne w Polsce pod okupacja 1939-1945, red. Z. Zieliński, Katowice 1992.

Krahel T., Arcybiskup Romuald Jałbrzykowski w sowieckim więzieniu, „W Służbie Miłosierdzia", 6 (2005), nr 9.

Krahel T., Błogosławiony Henryk Hlebowicz, Białystok 1999.

\footnotetext{
37 AAB, Wspomnienia s. Heleny Mańkowskiej o abp. R. Jałbrzykowskim, [mps], s. 9-10.

38 AAB, A. Jałbrzykowska, Nasz stryj, Kraków 1972 [mps], s. 16; A. Szot, Arcybiskup Romuald Jałbrzykowski na białostockiej ziemi, s. 122-123.
} 
Krahel T., Dzieje Archidiecezjalnego Wyższego Seminarium Duchownego w Białymstoku, [w:] Archidiecezjalne Wyższe Seminarium Duchowne w Białymstoku 1945-1995. Księga Jubileuszowa, red. S. Hołodok, Białystok 1995.

Krahel T., Martyrologia duchowieństwa archidiecezji wileńskiej 1939-1945, Białystok 2017.

Krahel T., Między wyzwoleniem a końcem wojny, [w:] Archidiecezja wileńska w latach II wojny światowej. Studia i szkice, red. T. Krahel, Białystok 2014.

Krahel T., Zarządzanie archidiecezją wileńską w czasie II wojny światowej, „Studia Teologiczne. Białystok Drohiczyn Łomża”, 4 (1986).

Kumor B., Granice metropolii i diecezji polskich (968-1939), „Archiwa, Biblioteki i Muzea Kościelne", 22 (1971).

List pasterski, WMW, 1 (1926), nr 1.

Łossowski P., Litwa a sprawy polskie 1939-1940, Warszawa 1982.

Mikłaszewicz I., Polityka sowiecka wobec Kościoła katolickiego na Litwie 1944-1965, Warszawa 2001.

Moroz M., "Krynica”. Ideologia i przywódcy białoruskiego katolicyzmu, Białystok 2001.

Paszkiewicz M., Dziesięciolecie rządów arcybiskupa Romualda Jałbrzykowskiego w Biatymstoku (1945-1955), „Wiadomości Kościelne Archidiecezji w Białymstoku”, 6 (1980), nr 2.

Paszkiewicz M., Ś. P. Arcybiskup Romuald Jałbrzykowski wzorem kapłana, „Wiadomości Kościelne", 1 (1957), nr 4-5.

Pietkun W., Kazanie wygłoszone wieczorem w dniu zgonu Arcybiskupa w kościele św. Rocha, „Wiadomości Kościelne”, 1 (1957), nr 4-5.

Rutkowski F., Arcybiskup Jan Cieplak (1857-1926), Warszawa 1934.

Szot A., Abp Romuald Jałbrzykowski metropolita wileński, Lublin 2002.

Szot A., Arcybiskup Romuald Jałbrzykowski na białostockiej ziemi (1945-1955), [w:] Między Wilnem a Białymstokiem, red. T. Kasabuła, J.J. Milewski, Białystok 2005.

Tomaszewski L., Kronika wileńska 1941-1945, Warszawa 1992.

Tomaszewski L., Wileńszczyzna lat wojny i okupacji 1939-1945, Warszawa 1999.

Wisner H., Litwa. Dzieje państwa i narodu, Warszawa 1999. 